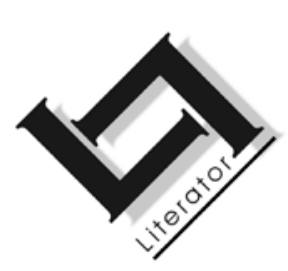

\title{
Some aspects of gender inequality in selected African literary texts
}

\author{
L.L. Kwatsha
}

Department of Language \& Literature

Nelson Mandela Metropolitan University

PORT ELIZABETH

E-mail: linda.kwatsha@nmmu.ac.za

\begin{abstract}
Some aspects of gender inequality in selected African literary texts

This article focuses on gender inequalities in selected African literary texts. I explore the way in which some African writers view gender inequalities and stereotypes in their characters. We will also be able to see who is involved and affected by these gender inequalities and how. Gender theory will be used as a framework. The aspects of gender that are discussed, include gender stereotypes, gender roles, gender identity, the superiority of men, inequality in polygamous marriages, sex roles, the sexual division of labour and arranged marriage. This study will also include the views of writers from other part of Africa. These views have a lot in common but sometimes they vary because of the influence and different ideologies of the society concerned.
\end{abstract}

\section{Opsomming}

\section{Aspekte van geslagsongelykheid in geselekteerde literêre werke uit Afrika}

Hierdie artikel fokus op geslagsongelykhede in geselekteerde literêre werke uit Afrika. Ek ondersoek die wyse waarop sommige skrywers van Afrika geslagsongelykhede en stereotipes in hulle karakters sien. Ook sal gesien kan word wie betrokke is en wie deur hierdie ongelykhede geraak word en hoedanig. Geslagsteorie sal as 'n raamwerk gebruik word. Die aspekte van geslagrolle wat bespreek word, sluit in geslagstereotipes, geslagsrolle, -identiteit, die superioriteit van mans, ongelykheid in poligame huwelike, die verdeling van arbeid gebaseer op ge- 
slag en gereëlde huwelike. Die artikel sluit ook die menings van skrywers van ander dele van Afrika in. Dit is opmerklik dat hulle sienings sterk ooreenkom, maar soms verskil as gevolg van die invloed en die verskillende ideologieë van die betrokke gemeenskap.

\section{Introduction}

Pilcher and Wheelehan (2004:56) state that the concept of gender, as it is used today, came into common usage during the early 1970s. They further state that it was used as an analytical category to draw a line between biological sex differences and the way these are used to inform behaviours and competencies, which are then assigned as either "masculine" or "feminine". In this article the term gendered will be used when analysing certain issues. Something is said to be gendered when its character is either masculine or feminine, or when it exhibits patterns of difference by gender. It gives expression to action, or doing of gender and it signifies outcomes that are socially constructed and gives men advantages over women.

The term gender has been used to refer to social, cultural and psychological aspects of masculinity and femininity. Gender is also known as the amount of masculinity or femininity found in a person. Gender is defined by Scott in Zinsser (1993:54) as

[a] constitutive element of social relationships based on perceived differences between the sexes, the knowledge that establishes meanings for bodily difference ...

This extract emphasises the social differences between female and male and it is this difference that prevents women and men from participating equally in social, political, economic and cultural life. Stanley (quoted in Jackson \& Scott, 2002:31) states that gender refers to culturally ascribed notions about "femininity" and "masculinity". Gender is used as a basic category, and once people decide what you are, they interpret everything you do in the light of that. Gender means the socially defined capacities and attributes assigned to persons on the basis of sexual characteristics. People make gender attributions; they decide whether someone is male or female when they see them. These gender attributions form the foundation for understanding other components of gender such as gender roles (behaving like a female or male) and gender identity (feeling like a female or male). 
Sex is related to gender. Some people even confuse sex and gender or sometimes they are used interchangeably. Sex refers to the physical, biological components of masculinity and femininity (Ogundipe-Leslie, 1994:153). There are two sexes, male and female, and correspondingly, two genders, masculine and feminine. Kessler and Mckenna (1978:7) indicate that if gender and sex mean different things, then they ought not to be used interchangeably; if they mean the same thing, then the cultural/biological distinction may be open to question. Delphy (quoted in Jackson \& Scott, 2002) concurs with the above statement when he writes that recognising the independence of the genders from the sexes should have let us to question whether gender in fact is independent of sex. Sex itself marks a social division; it serves to allow social recognition and identification of those who are dominators and those who are dominated.

Patriarchy is very important in the discussion of gender issues. Pilcher and Wheelehan (2004:93) say that patriarchy literally means "rule by the male head of a social unit" (a family or tribe). It also refers to the elder who has power over others in the social unit including other men, women and children. Feminists have used the term to refer to the social system of male domination over women. Ruthven (1984:2) contends that the task of feminist critics is to expose the way in which male dominance over females constitutes perhaps the most pervasive ideology of peoples' culture and provides its most fundamental concept, namely power. In her theory of patriarchy, Walby (1990) defines patriarchy as a system of social structures and practices in which men dominate, oppress and exploit women. She identifies six structures of patriarchy: household production, paid work, the state, male violence, sexuality and culture. Some of these structures will appear in the application and discussion of the article.

Male domination is very pervasive in African society. Women are regarded as "honorary children". The female is not regarded as a "whole" being; she is viewed as unfinished, physically mutilated and emotionally dependent. On the other hand, men are designed to be dominant.

Gender inequality is linked to the relationship of power between the sexes. McKinnon (quoted in Kramarae \& Treichler, 1986:174), further emphasises the above statement:

Gender is a division of women and men caused by the social requirements of heterosexuality, which institutionalizes male sexual dominance and female sexual submission. 
When we look at the above definition, we notice that sexuality is one of the causes of gender inequality. The differentiation between the genders gives the male the social power and dominance because of the penis that he possesses and women, on the other hand, suffer sexual submission because of the small space that they possess (the vagina). In this case, an individual is not looked at as a "whole" being, but as a "part". Christine Bond (quoted in Rohrbaugh, 1981: 260), says:

... I often say that, just because I was born packing a vagina doesn't mean that I want to be identified by that small space; I want people to deal with the whole of me and what I am about.

Gender stereotypes also play a role in social inequality. Some people socialise themselves according to these stereotypes with the awareness that it is their way of living, unaware that they are creating a boundary between themselves and others (male and female). Gender stereotypes are defined by Galombok and Fivus (1994) as organised sets of beliefs about the characteristics of all members of a particular group. Gender stereotypes are sets of beliefs about what it means to be female or male and include information about physical appearance, attitude and interest, psychological traits, social relations and occupation. Most important, these various dimensions are interrelated; simply knowing that an individual is female implies that this person will have certain physical characteristics (soft voice, dainty, graceful actions and certain psychological traits - nurturing, dependent, weak, emotional) and will engage in particular kinds of activities (child care, cooking, gardening). These stereotypes can result in gender inequality, especially if people do differentiate their roles according to gender.

From childhood, people are surrounded by gender stereotypes. According to Eckert and McConnell-Ginet (2003) gender is embedded so thoroughly in social institutions, community actions, social beliefs and people's desires, that it appears to society as completely natural. Gender is not something people are born with, and not something people have, but something people do, something people perform. Some of these gender activities and spheres have greater power and prestige than others; a division of labour can also be a division of social value. Across societies, the gender division of labour involves differential power and status. Men, in most cultures, have more access to positions of public power and influence than women, while women, in most cases, wield considerable influence in the domestic setting or in other non-public domains. Robinson et al. (quoted in Rohrbaugh, 1981:80), assert that: 
... housework is for women only. Regardless of how busy his wife may be with a paid job, the husband rarely takes on any of the household chores.

A housewife is a person, other than a domestic servant, who is responsible for most of the household duties. Housework is described as a never-ending job. Clayton (1989:289) quotes the voice of Tlali when she says "to say woman is to say pot, to say woman is to say broom". This means that women are associated with the kitchen. Jones and Olson (1991) explain that according to a Pakistani proverb, the place of women is in the home or the grave. A similar North American saying goes that a woman should be kept barefoot, pregnant and in the kitchen.

In most places, society dictates that the male is the more valued child. In this regard Brown-Guillory (1996:163) asserts:

A daughter is raised by a mother to be a nurturing and caring person. The daughter is taught to care for others in the family and to believe in the ultimate value of the family ... favouritism to the son damages not only the daughter but also society.

The division mothers make between their children of different sexes affects their daughters' womanhood. They become man's dependents, if not his slaves, because from their childhood they have never shared the world in equality. In other cultures, to give birth to a girl is the start of marriage problems. For instance in India, Mohanrom (quoted in Brown-Guillory, 1996) argues that the misogyny and devaluation of daughters leads mothers in India to hope for a boy when they are pregnant because girls do not strengthen or enhance their lineage; they merely function as objects of patronymic exchange. A female child does not contribute to securing power for the maternal position. In Indian culture a woman brings honour and power to her family when she gives birth to a boy. The mothers in Indian communities teach their daughters how to bend properly in order to serve their men and be content with women's fate. The Olinkan mothers also see a need for their daughters to be silent, as they perceive silence as the step on the path to becoming a woman in their culture. Brown-Guillory (1996:6) explains that

[t]hey are taught that pain is not to be given a voice, which often results in insanity. Those who can withstand pain go on to teach their daughters to work hard, produce children, and endure pain. 
Daughters of Olinkan society undergo circumcision in order to be seen as complete women. This is a tradition that needs to be passed by mothers to their daughters, if she is to be a good mother in that cultural society. Nwapa, in her interview with James (1990: 113), states:

The oppression of women starts in the home. In our homes today we treat girls differently, and we treat boys as if they are kings.

African mothers or women, taking traditional Xhosa customs as the norm, do prepare their daughters to bring a good lobola. They teach them how to do house work and to work in the fields. They also show them how to dress as women and they teach them to show respect to any male person in the society.

This article will examine how some aspects of the portrayal of gender inequality in selected texts affects the characters involved. The way in which these inequalities affect the lives of characters is also explored.

\section{Gender stereotypes}

Gender stereotypes are also signs of gender inequality. It is said that these stereotypes are actually important in socialising women and men to accept inequality. According to Pilcher and Wheelehan (2004:166) the concept of stereotype was introduced into social science in 1922, when Lippman used it to describe the "typical picture" that comes to mind when used about a particular social group. Stereotypes thus do not necessarily reflect reality; rather, they represent culturally shared beliefs about what particular individuals will be like. Whether or not it is true that females are soft, dainty, nurturing creatures, we know that this is the cultural version of what it means to be feminine. Stereotypes would suggest many differences between males and females, but often they have no basis in real behaviour. Galombok and Fivus (1994) state that we must keep in mind that what we believe about gender differences may or may not be true. They further maintain that culturally prescribed stereotypes do express those characteristics that are considered socially desirable for women and men to possess.

Some people believe that men have to perform only men's jobs and others feel the other way round, that any job is for anybody, whether male or female. Some women in this new and stressful environment come to rely heavily on the gender stereotypes instilled in them from 
childhood to conform to social norms and control their feelings of hostility.

\subsection{Gender role identity}

Gender identity means to feel like a female or a male. This means that it refers to an individual's own feelings of whether she/he is a woman or a man, or girl or a boy. Gender role identity refers to how much a person approves of and participates in feelings and behaviours, which are seen as appropriate for his/her gender. In traditional male role identities women are often seen as inferior to women. According to Papanek quoted in Tinker (1990:180), through these convictions seeds of inequality are

... planted deep in the consciousness of women and men, often by other women, who perceive their self interest to lie in the hands of men rather than other women. But since inequality depends on social learning in the first place, it can also be unlearned.

People learn to accept their life circumstances and to submit to the norms and expectations of the group to which they belong. A traditional superior male role identity is clearly at issue in Mothlabane's drama, linkunzi Ezimbini. Sibonda is telling Gcisa, his neighbour, about Nolasti, his wife, who answered him back at home:

Sibonda: Zakhe zakhonya na inkunzi ezimbini ebuhlantini obunye Gcisa? Yinto esiza kuyithini le ivelele usapho lukaPhalo? Uthi uyindoda njani xa uphendulana nabafazi emzini wakho?

(Mothlabane, 1994:11.)

Have two bulls ever bellowed in the same kraal? What are we going to do with this thing that overshadowed Phalo's homestead? How can one describe yourself as a man when you allow women to answer back in your own house?

Sibonda is incapable of speaking to women as equals. His attitude shows that he wants to patronise the women, not to talk them as an equal, but as superior and wiser. He does not expect his wife to object to his ideas or observations. He feels threatened when a woman exchanges words with him because he thinks that this will lower his authority and status as a man. According to him, society expects him to be able to take care of his wife. Men are not supposed to allow their wives to disagree with them because that shows lack of respect from their wives. 
How deeply this gender role identity is ingrained in women emerges from Nofinishi's words. Nofinishi is angry at Nolasti's Westernised behaviour within the homestead.

Nofinishi: Usimele ngempucuko yokuba yena akanakuphathwa yincentsa. Ndixakwa kukuba wayeze kuthini apha kanti ufuna ukuziphatha ... Bayafuna ukuba ngabafazi kodwa abakwazi tu ukwenda. Lo Nolasti ungafika engqayiza, ezibiza ukuba yena uyinkosikazi kaJwarha uqobo ezingomba isifuba kuba etshate ezi-ofisini zeemantyi, inqaba kukuziphatha okwenkosikazi. (Mothlabane, 1994:14.)

She has been telling us about the progressive ideas that she cannot be ruled by a man. What amazes me is, what was the point of her coming here if she wanted to rule herself ... They want to be wives, but they do not know what it means to be a wife. This Nolasti, you can see her boasting, calling herself Jwarha's wife, also boasting about marrying at the magistrate's court, but the problem is that she does not know how to behave like a wife.

From these words we can see that Nofinishi represents the ingrained sense of inequality in believing that her best interest lies in the hands of her husband, Sigqibo, and not with other women. She believes that to be married is to do what your husband wants you to do because you are under his control. She also believes that if you are a woman and you maintain that you are married, you must behave the way a married woman is supposed to behave according to her and her society's expectations, that is to be loyal and be submissive to her husband's needs. Ogundipe-Leslie (1994:49) indicates that rural women are mostly portrayed as uncreative. Bound by tradition and culture, rural women are constantly depicted as closed to or frightened by new ideas, limited to their narrow world, interested only in what affects them in their small environment.

The above two quotations from Sibonda and Nofinishi demonstrate that both men and women have internalised the idea of inequality. They see it as a normal thing to do. Nofinishi is depicted as bound by the tradition and culture of her people.

Sibonda, in Inkunzi ezimbini, also emphasises these gender stereotypes when his wife, Nolasti, takes the decision to accept working overtime in order to get more money from her employer:

Sibonda: Uvume njani Nolasti? Uyivuma njani into elolo hlobo ungakhange ugqithe kum? Uthetha ukuba 
uza kusuka uzigqibele ukuba unokubuya nanini na xa uthanda, apha emzini wam? (Mothlabane, 1994:17-18.)

How could you accept it, Nolasti? How could you accept something like that without consulting me? So you think you are going to take your own decision to come into my house at any time [you wish]?

Sibonda confirms the idea that the tasks that women and men carry out in life are viewed differently by different sexes. Sibonda expects his wife not to make any decisions without his consent as a man. This means that even if Nolasti is interested in accepting the offer from her madam, if her husband does not approve, she cannot go further with it. These stereotypes are viewed as ingrained images in society's mindset. They are difficult to change. This demonstrates the inferior position that women hold in society and in their homes. This also shows how culture commands women to succumb to the will of men.

Nokhaya's words also portray the idea of gender role identity. She tells Nolasti, her co-wife, who is more enlightened than her, that there is no time to rest because their husband is on his way. They cannot have time to themselves to sit down and relax, even if they are tired. Their whole life is meant to satisfy their husband Sigqibo. They believe that it is their duty and a woman's task to look after the well being of her husband by making sure that he is happy. They do not want to be seen by their husband sitting down (relaxing). They must be seen working all the time, although their husband is going to come home and relax. Nokhaya is one of the women who enjoys being a wife and who enjoys working like a slave for her husband:

Nokhaya: Hayi wethu akukho xesha lakuphumla ayeza la mancentsa, kuza kuba njani xa esifikela sithe dudlu apha sonke? Phumla wena ukuba uyafuna usiyeke thina sisebenze." (Mothlabane, 1994:7.)

No, there is no time to rest, these men are coming. How will it be when they arrive seeing us sitting here? You can rest if you want and leave us to work.

As women and wives, Nokhaya and other women perceive themselves as having no right to relax. Their men must see them busy all the time. They give in to the authority and control of their husbands even if the circumstances do not allow this. According to traditional culture, a woman shows no form of respect if she sits down at her 
husband's homestead as if there is no work to be done. This shows that they live in a male dominated culture where women's needs and feelings are not acknowledged and where women are forced into sex roles which deprive them of their happiness.

Ogundipe-Leslie (1994:154) states: "Sex is used to exclude women from power and privilege and hijack material benefits from women."

The slave girl by Emecheta (1995) portrays the acceptance of inequality and identification of gender roles by both females and males. Ma Palagada, who is a well-known trader, gets slaves from outside by paying for them so that they can help her with her trade and with domestic work. But because a woman is seen as powerless, Ma Palagada does not own the slaves for whom she pays, but Pa Palagada does, because he is a man. Gender is used to exclude Ma Palagada from the power she deserves. Pa Palagada is not involved in trading. He stays at home abusing female slaves and waits for his wife to come back from work. The credit is not attributed to the one who works hard for it, but to the person who did not do anything:

It was a known fact that although Ma Palagada was the one who had bought them, they ultimately belonged to Pa Palagada and whatever he said or ordered would hold. (Emecheta, 1995:113.)

Ma Palagada sees no alternative but to live by these norms and to accept that she is powerless, although she is the one who has the financial power in her hands. Ma Palagada does not have a right to reprimand her husband because she is a woman, and societal norms and values do not allow a woman to show a man his bad side.

In Emecheta's The slave girl, Pa Palagada views women in a way that shows gender stereotypes:

He was one of those big, manly males who would not hesitate to tell you that women were created as play things for men, that they were brainless, mindless and easily pliable. (Emecheta, 1995:178.)

This shows that gender stereotypes often are the only dimension of people's understanding of others. Pa Palagada does not view women other than as sexual objects for men. Ruth (1980:18) says stereotype is a concept related to role, yet distinct. 
NnuEgo in Emecheta's The joys of motherhood (1998) finds it difficult to leave behind one of her youngest daughters the day she returns back to her home from Lagos. The reason for this reluctance is that Obiageli plays an important role in giving her entry into womanhood by being her child. Obiageli gave NnuEgo identity as a woman and as a mother:

... NnuEgo replied with tears in her eyes, 'I don't know how to be anything else but a mother. How will I talk to a woman with no children? Taking the children from me is like taking away the life I have always known, the life I am used to.' (Emecheta, 1988:212.)

The author emphasises women's commitment to their motherhood and the fact that children are the key to their womanhood. NnuEgo identifies herself with other mothers. Because of her commitment to her womanhood and to her motherhood, she never had a chance to build friendships with other women. Her only concern in life was the joy of being a mother:

She had never really made many friends, so busy had she been building up her joys as a mother ... the joy of being a mother was the joy of giving all to your children, they said. (Emecheta, 1988:224.)

In Buzani kubawo by Tamsanqa (1987) MaGaba, Zwilakhe's wife, is bound by patriarchal rules, so that she cannot be involved in the family discussion of her son, Gugulethu's, arranged marriage. MaGaba shows her concern by saying:

MaGaba: Kanti ukuba bekuthetha mna bekungekho ntombi yimbi ibiya kuthathwa nguGugulethu ngaphandle koThobeka. (Tamsanqa, 1987:2-5.)

If I were the one who had a say, there would be no girl who was going to be married by Gugulethu except for Thobeka.

MaGaba shows the patriarchal restriction of her powers as a woman in her homestead. MaGaba gives a voice to her wish to her husband, Zwilakhe, because she cannot be part of the meeting to discuss Gugulethu's arranged marriage. MaGaba, because of traditional norms of African society, has a minimal role to play in planning her son's future because of her sexual identity.

Patriarchal society commands women to go with the will of men. In the patriarchal society men, as the heads of families, want things to go their way. In Inene nasi isibhozo Mfolo, Masukude's late hus- 
band's brother, displays dissatisfaction about Masukude's presence in the family meeting, although they are discussing issues that concern Msukude's home. Mfololo says:

uMfolo: Lo ke umfazi uza kwaneka umcimbi womzi emadodeni uza kusanekela ngani? (Mtingane, 1992: 24.)

This wife who is going to say something concerning the homestead in front of men, how is she going to present it?

According to Reber (1985:640), Masukude's feelings are being repressed by her in-laws. Repression refers to the limitations put upon one group's or individual's freedom of expression and action by a dominant group or individual. Masukude, as a woman, has been limited by the man in her family of a freedom to express her feelings in the meeting that concerns her homestead, but because she is a wife and a woman, she is not allowed to take part. She will accept whatever decision is made, even if she does not agree with it.

\subsection{The superiority of men}

Women's acceptance of their lives with their husbands reaffirms the demands and expectations of traditional culture and patriarchy, that women should be submissive to their husbands' actions towards them. Submissiveness is part of repression. Nofinishi and other women are compelled to repress their feelings and live according to their superego, so that they will not be outcasts in their society. They want to be taken as obedient women. Mothlabane also portrays gender stereotypes by giving us an example of a woman who believes that a man is the head of the house because he supports, clothes and protects women.

Nofinishi: Awukwazi nokuhlonipha kodwa uthi ungumfazi! Ityhontsi yintloko, yile nto ke ayiyo uyise kaMandla apha kuthi. Uyasondla uyasinxiba, usikhusele, u ... (Mothlabane, 1994:7.)

You cannot even show respect, but you are saying you are a woman! A man is the head. That is what Mandla's father is to us. He feeds us, clothes us, protects us, he ...

Nofinishi is one of the women who totally accepts a man as the head of the house. Nofinishi's speech also emphasises that a man and his words should be law in his homestead. She also wants Nolasti to 
support and be submissive to her husband. Nofinishi, as a traditional wife, does not believe in challenging the authority of her husband.

Ojebeta, in The slave girl, takes what is happening in her life as the way things should be.

In her own way Ojebeta was content and did not want more of life. She was happy with her husband, happy to be submissive, even to accept an occasional beating, because that was what she had been brought up to believe a wife should expect. (Emecheta, 1995:178.)

The reason Ojebeta accepts the situation is that she was socialised in such a way that, as a woman, she had to accept what was being done to her by men. Ojebeta's acceptance of her life with her husband reaffirms the demands and expectations of traditional culture and of patriarchy, that women should be submissive to their husbands.

Women's submissiveness to their husbands is shown in The joys of motherhood when NnuEgo witnesses in the court of law and she agrees that she is the one who provides for the family, but, because she is a woman, she bestows her hard work for the family on her husband, Nnaife:

Nnaife is the head of our family. He owns me, just like God in the sky owns us. So even though I pay the fees, yet he owns me. (Emecheta, 1988:217.)

Traditional men do not want women who want to overpower them in their houses. They want to feel that their wives are under their control. Dyafta, in Ikamva lethu, shows how men have to be given respect by their wives. This is evident from the minister's words when he was giving words of wisdom to Nonzwakazi on her day of marriage:

... uze uyoyike nje ngoyihlo indoda yakho, yaye ilizwi lakho ze lingaze libe lelokugqibela endodeni yakho, uzifundise ukuba uthi yakuthi pheza upheze nokuba uyaqonda ukuba yiyo ephosisileyo (Dyafta, 1953:49).

... you must be afraid of your man as you are to your father and your voice must never be the last to your husband. You must teach yourself that when he says stop, you must stop, even if you know that it is he who is off the track. 
Men hold the most respected positions in traditional society. They are viewed as superiors who hold high status as the head of the house. Nonzwakazi is being indoctrinated on her day of marriage that she needs to be afraid, be submissive and give her husband respect, so that if she strays she can be reminded of the minister's words of wisdom. This means that these words provoke a guilty conscience in Nonzwakazi so that she can remain loyal and submissive at all times.

Women in marriage do not get a chance to come up with their own views. Men want to be the people who make decisions and final arrangements in the family. Sigqibo uses his superior status as the man to undermine Nolasti's idea. According to Rohrbaugh (1981) the male penis is a symbol of social status and power. This is seen in the dialogue between Sigqibo and his wife, Nolasti, when they are arguing about taking their son to a boarding school.

Sigqibo: Yibambe apho kanye. Andizukuxelelwa nguwe ukuba yintoni ebalulekileyo nengabalulekanga ngomntwana wam. (Mothlabane, 1994:28.)

Hold it there. I am not going to be told by you what is and what is not important about my child.

Nolasti is also Luvuyo's mother, and she has every right to make decisions about her son's future. But Sigqibo views Nolasti's suggestion as that of a minor, which is why he decides to dispute it and put his views forward.

Sigqibo: Elokugqibela iseleliya lokuqala, uLuvuyo uza kufunda apha eMachubeni (Mothlabane, 1994:28.)

The last is still the first one, Luvuyo is going to study here at Machubeni.

Marshall, quoted in Jarrett-Macauley (1996:16), says: "Men just see us here as breeding animals. I don't think they see us as women who have a right to say what we want." Sigqibo is not interested in asking Nolasti the reason for her suggestion, but because it comes from her as a woman, he does not want to give it a chance, as he will be viewed as a person who listens to women's views about his son. Sigqibo reaffirms the idea that women are social castrates by disputing Nolasti's ideals for their son, Luvuyo. 


\subsection{Polygamy}

Mbiti (1969) contends that polygamy primarily has to do with the importance of immortality among African people. According to him, longevity is extremely important. In this regard, offspring prolongs one's life through an elaborate system of ancestry. The more children one has, the greater the probability of being remembered. Lee (1982) notes that women desire co-wives because it increases the production of the family, thereby increasing the overall status of the family. In a polygamous marriage, women have to tolerate each other, even if the situation does not warrant that. They have to do it out of respect for their husband. This is disadvantageous to them because they do not have the chance of getting to know their husband as they wish, because he has to give each one of them a chance to be with him. Sometimes he does this in such a way that one feels that she is being abandoned. This may result in a quarrel between the two.

Mothlabane, in linkunzi ezimbini, shows how a man with several wives pays each of them a visit and how it affects some of them. This is seen in Sigqibo's words when he is talking to one of his other wives, Nolasti, who wants to have a say in their home decisions. Nolasti is being deprived of the time spent with her husband, because she showed an independent voice and she wants to have a say in the household matters. The African traditional belief that men are the ones who make decisions in their homes, and the expectation that women and wives should be submissive to their men and to their husbands, acts against Nolasti's happiness in her polygamous marriage.

Sigqibo: Le nto ingazange ibe yingxaki nje kubafazi ababekho ngaphambili kwakho kweli khaya yintoni? Uyaqaphela phofu ukuba uNokhaya noNofinshi bonwabile kuba bona bayayazi indawo yabo? Wena lo ukhalaza rhoqo usithi ndichitha ixesha elininzi ndincokola nabo ngaphezu kwakho, into ongafuniyo ukuyiqonda kukuba xa ndikunye nabo andikho dabini lamagunya njengokuba kusiba njalo xa ndinawe. Nangoku nje ukuba ubundimamele kwakuqala ngale nto kaLuvuyo, ngesesincokola ezimnandi ngoku. Kodwa ke kuba wena wasoloko uyiphikisa into endiyithethayo, siyawaxambula ke nangoku. Ingaba akuyiboni le mpazamo yakho? (Mothlabane, 1994:29.) 
This was never a problem to the wives before you in this house, why? Do you notice that Nokhaya and Nofinishi are happy because they know their place? You're always complaining, saying I spend more time talking with them than I do with you. Something that you do not want to understand is that when I am with them, I am not in a battle over rights as it is when I am with you. Even now, if you had listened carefully about Luvuyo's issue, we should have been talking about happy things now. But because you always dispute everything I say, we are quarrelling now. Can't you see your mistake?

Another disadvantage of polygamy is that men tend to make comparisons among their wives, so this puts some at a disadvantage. That is why these women will try by all means to satisfy their husbands because they know that if they are lacking in one way or another, he will not visit them. It is not a good feeling to see your husband passing through your house to sleep with another woman.

In most cases women are not allowed to have more than one husband. This is evident in the following words from Ojebeta:

So men would simply take wives if they felt like it, while women, on the other hand, must have one husband, and only one. (Emecheta, 1995:178.)

Nwapa, in Efuru, portrays Efuru as a wife who does not have children in her marriage. Because of that Efuru gives her husband permission to have another wife because her younger co-wife, Nkoyeni, is giving trouble. Efuru utters these words to her mother in-law:

'We want to marry again', Efuru said laughing. 'Really, why?' 'Eneberi wants to marry another wife, and I think it is the right thing to do. Nkoyeni is giving us trouble, ... we must get another wife who will compete with her ...' (Nwapa, 1994:214.)

Efuru has accepted that a man is supposed to have as many wives as he likes. Instead of acting against that she decided to be part of it. It is also her jealousy of the younger wife that makes her part of the decision to take another wife so that their husband cannot concentrate on Nkoyeni, the younger wife. From an African traditional point of view, women are not supposed to show any jealousy towards their co-wives in a polygamous marriage. They have to see each other as a supporting system to share household chores.

In The joys of motherhood jealousy among the co-wives is evident. NnuEgo and Adaku are jealous of each other. They compete using 
their children (NnuEgo has sons and Adaku has given birth to girls) and their own success in trading.

She did everything she could to make Adaku jealous of her sons. She looked for every opportunity to call the names of her children in full, telling herself she was having her own back. Minor quarrels started between the two women, and Ubani, Nwakusor and their friends were usually called in to settle the disputes. (Emecheta, 1988:162.)

This jealous, based on the value of children or inequality among children, is a way of impressing on the children that they were not born equal. This will affect them in life, because, from their childhood on, they have never shared the world in equality.

\subsection{Gender and sex role stereotypes}

A gender role is a set of expectations about what behaviour are appropriate for people of one gender. Some writers agree with this idea, but some refer to it as sex role, e.g. Yorburg (1974). Mill, quoted in Jones and Olson (1991:202), states:

All women are brought up from the very earliest years in the belief that their ideal of character is the very opposite to that of men, not self will, and government by self control, but submission, and yielding to the control of others.

\subsubsection{Gendered division of labour}

Mazumdar and Sharma quoted in Tinker (1990) observe that the gendered division of labour has been considered a key variable in the analysis of women's subordination. In many cases, work is divided according to people's sex. People grew up knowing that there are male and female jobs. Children are socialised early in their lives as to what their roles will be when they reach adulthood. Girls grow up knowing that a woman's place is in the kitchen where she has to keep herself busy with household chores such as cooking, washing, sweeping, and so on. Krige (1974:184) expresses it thus:

On the whole, the rougher tasks requiring strength are done by the men, while to the women falls the work that requires more continuous attention. The housework naturally falls within the sphere of woman's activities and cooking and beer making, sweeping, washing of utensils and the fetching of firewood and water are the work of women. In this, they are helped by their daughters, who at an early age begin to fetch water, sweep, and look after their baby brothers and sisters. 
Krige emphasises the idea of job differentiation between the sexes. Women's work is more domestic and requires constant attention, although the people who benefit from it look down upon women's work. Swartbooi, in UMandisa, portrays what Krige described about women being involved in different work around the house.

Nanko uMamNzothwa eququzela phakathi kwaloo mzi sesiwuchazile. Yonke into ijonge yena, njengokuba kungekho mantombazana. Kangangokukhuthala kwakhe, wayengawazele nto umsebenzi konke waloo mzi wakhe, kuba wayeqhele kwakowabo kwaBambela, ukusebenza ngolu hlobo. (Swartbooi, 1975:7.)

There is MamNzothwa busy around the home that we already talked about. Everything is waiting for her, as there are no females. She was so quiet in such a way that she did not even feel the load of her homestead work because she was used to this kind of work from her Bambela home.

Swartbooi depicts a woman who loves her housework. MamNzothwa has learnt her housework at home. She was socialised in a way to know that domestic work is for women. In linkunzi ezimbini, Sigqibo does not want to go to the kitchen to fetch a piece of meat for himself because he claims that as a man, he cannot go into the kitchen. This means that he sees the kitchen as a woman's place.

Sigqibo: Nokwenza ndikuthuma ezimbizeni apho ndingenakuya mna. Uthi mandithini ke, ndiye kujingisa intshebe ekhitshini ndinomfazi? (Mothlabane, 1994:38.)

For that matter I am sending you to the pots where I cannot go. What must I do, must I go with a long beard into the kitchen having a wife?

Nolasti is one of the women who desires to change, but she is seen as a bad woman while Sibonda, her husband, sees her attempt to cope with the changing world as a problem and a betrayal of traditions. As a woman she is expected to do what her husband asks her to do. Her husband does not expect her to challenge anything that connects her with the kitchen, because in African traditional beliefs pots and kitchen means woman. Eckert and McConnell-Ginet (2003:9) emphasise that people are surrounded by gender lore from the time they are very small. Aspects of gender are ever present in conversation, humour and conflict. Gender is embedded thoroughly in pupils' institutions, people's actions, their beliefs and their desires. To many people gender seems natural. In the 
novel UMandisa (Swartbooi, 1975:10-11), issues of gender stereotypes are revealed.

'Ngumtshato wani, na, Mandi, lo ungomso, ndingakhange ndiwuve?'

'Ngowoonopopi, mama ...' Nanko ebaleka egqotsile ukuya koonopopi bakhe, kaloku wayakhelwe indlwana yabo efekethiswa ngomnye wabaninawa bakayise.

'What marriage is there tomorrow, Mandi, because I have not heard about it?'

'It is for the dolls, mother ...' There she runs to her dolls. She had a small doll's house built for her by her father's younger brother.

Playing with dolls and mock marriages and cleaning the house are all based on a gendered division of labour and designed to instill these gender-defined roles. From her childhood, Mandisa was indoctrinated regarding the issues of gender. During her playtime she knew what to play with and what character to play. Mandisa was empowered by female games and female activities. She belonged to a subordinate group and the condition of subordination is socially determined. She followed all the steps that her mother took, fetching water from the river, and using cow dung to smear the house. This is evident in UMandisa (Swartbooi, 1975:15):

... 'Kaloku mntwanam, kufuneka umke selekhe wandingqushisa, wakha namanzi.' Ungqushile uMandisa emana ekhwezela nomlilo ungacimi.

... 'My child, you must stamp mealies and fetch water before you leave.' Mandisa stamped the mealies and she also looked after the fire so that it wouldn't burn out.

Women are accustomed to raising their female children to learn and do the things they themselves learned from their mothers, thereby continuing the vicious circle, just like MamNzothwa did with Mandisa. MamNzothwa, Mandisa's mother, socialises her child, Mandisa, to do housework in her early life. Mandisa grows up knowing that stamping mealies, fetching water and similar jobs are girls' or women's work. When she is an adult, she will continue doing the same because that is what she was taught by her mother.

Gilman, quoted in Jones and Olson (1991), posits that it is not motherhood that keeps women on their feet from dawn till dark; it is 
house service, not child services. This is evident in linkunzi ezimbini when Nokhaya takes the tin to get water from the river in order to get fresh water to make tea/coffee for her husband.

Nokhaya: (Equbula inkonkxa esiya kukha amanzi.) Makhe nditsibe emlanjeni bafazi adiniwe la manunga akule nkumba. Uza kufika efuna ishi ephungwayo uBawo abe ke akawafuni amanunga amadala. (Mothlabane, 1994:6.)

(Taking a tin to the river.) Let me go to the river, women, the water in this tin is old. Father will come and ask for something to drink and he does not like old water.

Nokhaya shows dedication to her domestic work. She accepts the idea that women's work revolves around the kitchen and that includes the fetching of water from the dam. She knows that what she is doing is part of the daily work she has to perform. That is why she feels guilty giving her husband old water. She will see herself as a failure as a woman if she cannot fulfil her domestic duties as prescribed by social stereotypes.

Mtingane, in Inene nasi isibhozo, displays the role of a woman when the men of the family ask Masukude to go and fetch water instead of being part of her home family meeting:

UMfolo: Masukude, thatha iemele uyokukha amanzi upheke, sakubiza xa sikufuna. (Mtingane, 1992: 25.)

Masukude, take the bucket and fetch water and cook. We will call you when we need you.

In the above passage Mfolo reminds Masukude of her domestic role of fetching water and cooking. Tompkins, quoted in Bressler (1994: 102), states that what enrages her is the way women are used as extensions of men, mirrors of men, devices for showing men off, devices for helping them get what they want. They are never, or rarely, there in their own right. Nokhaya and Masukude above had to do what the men said or what their men expected of them. They are seen as dependent on the men's decisions and expectations. Women like Masukude are portrayed as not being decision-makers in their families, but as followers of their male counterparts and their decisions. 


\subsubsection{Gender role stereotypes}

It is believed that even if women do not become mothers, Rich (1977) argues, they cannot escape the oppression of the institution of motherhood. Rich also maintains that all women are defined either as mothers or as not mothers. If women do not bear children, then their childnessness is what defines them. Historically, cross culturally, a woman's status as child bearer has been the test of her womanhood. The phrase childless man and non-father sounds absurd and irrelevant to us. In African culture, barrenness is perhaps the worst affliction (even crime) a couple can endure, and it is always attributed to the woman. In African traditional society, for a woman to lack reproductive power is to lack all power.

NnuEgo in Emecheta's, The joys of motherhood, finds herself breastfeeding a child that is not hers. At this stage she identifies herself with the child as if the child is her own. She is fulfilling her wish to have a child by letting her co-wife's child suck her breast. NnuEgo feels a sense of inferiority, a sense of lacking the selfcontrol to master the tasks which her parents and the community at large set her. She wants to make this wish real, although it is not.

She looked at the child again. Why not breast-feed him herself? The mother wouldn't mind, she wouldn't even know. NnuEgo locked her hut, lay beside the child and gave him her virgin breasts ... The baby's restlessness abated and he sucked hungrily, though there was no milk ... (Emecheta, 1988:34.)

When NnuEgo lost her first son, she nearly killed herself because she knew that, according to her culture, she had wronged her husband. She uttered these words:

'The men make it look as if we must aspire for children or die. That is why, when I lost my first son, I wanted to die, because I failed to live up to the standard expected of me by the males in my life, my father and my husband and now I have to include my sons. But who made the law that we should not hope in our daughters? We women subscribe to that law more than anyone. Until we change all this, it is still a men's world which women will always help to build.' (Emecheta, 1988:187.)

NnuEgo's words show the disadvantage that childless women have in society. Childlessness often becomes such a stigma to them that they prefer to die rather than to live a stigmatised life. It mostly also is not just a child that a woman is getting credit for in her marriage, but a son. If a woman gives birth to daughters, it is as if she never gave birth to that family. African traditional society does not consider 
the fact that a man and a woman is necessary for procreation. If a woman gives birth to a girl, so does the man.

Weeden (1987:54) maintains that men, by virtue of their penises, can symbolically aspire to a position of power and control. In The joys of motherhood Emecheta shows the destruction and unfair rejection of a woman because she cannot have children. Amatokwu, NnuEgo's husband, utters these words to his wife:

I am a busy man. I have no time to waste my precious male seed on a woman who is infertile. I have to raise children for my line. If you really want to know, you don't appeal to me anymore. You are dry and jumpy. (Emecheta, 1988:32.)

Wilentz (1992:11) emphasises the value of children in marriage: "No matter how good a marriage is, the culture says it means nothing, unless there are children to show for it."

In the above scene NnuEgo suffers rejection by her husband because she cannot fulfil what her husband and her society expect of her. Amatokwu's rejection of his wife because she is infertile suggest that a man sleeps with a woman expecting results thereafter. He refers to his sperm as "precious seed". This is a way of belittling NnuEgo because she wasted this precious thing all this time by not getting pregnant.

In her novel, Efuru, Nwapa illustrated the performance of circumcision on young women by elderly women of the village. Efuru finds herself in a situation where she has to accept circumcision which is said to be painful.

You are a young wife, daughter. You are beautiful, my daughter. I will be gentle with you. Don't be afraid. It is painful no doubt, but the pain disappears like hunger ... you know Nwakaego's daughter? ... She did not have her bath before she had that baby who died after that dreadful flood. (Nwapa, 1979:10.)

These women keep inequality alive by continuing a custom. They want Efuru to agree to perform a bath because they link it to giving birth. If Efuru disagrees she will be told that she won't have children or that she will give birth to them, but they will die shortly thereafter. This indoctrination will force Efuru to agree because she wants to escape the stigma associated with childlessness. These women do not want to break the chain of inequality for their daughters. Instead they enforce it as elderly women did it to them. 
Papanek (quoted in Tinker, 1990) maintains that in many cases inequality is also cloaked in the veil of rational self-interest. In the novel entitled Isazela sidl' umniniso by Magadla (1992), MamQoma, who is Tozi's mother-in-law, is one of the elderly women who, because of the remembered pain of her in-laws watching her carefully to see whether she is pregnant, decides to inflict similar pain on her daughter-in-law by looking at her stomach each and every time she sees her to see whether she is pregnant. MamQoma still remembers how she felt when socialisation for inequality began in her own childhood, when the blame was always put only on women when the couple could not have children. It was not blamed on men at all. MamQoma is an example of a woman who does not want to break the cycle of inequality for the generation to come. She does not want to rebel against this stigma which is associated with women; instead, she wants to see to it that Tozi, her daughter-inlaw, does not have a happy marriage because she does not bear children. Tozi will sometimes blame herself for not conceiving in her marriage, whereas it was discovered that the problem was with her husband, not her.

UTozi waba namathuba okubhaqeka ehleli yedwa eceba ukuzoyelisela kwisizibakazi esikhulu seengcinga wayesithi akubuzwa ngakucingayo ngumyeni wakhe akhanyele alale ngomhlana esithi akukho nto ingako noko. (Magadla, 1992:15.)

Tozi had times of being seen alone thinking very deeply. When she was asked by her husband what she was thinking, she would reply saying there was nothing much.

Some people perpetuate inequality because they feel that they have to do it since people of their society are doing it. MamXebise, in Bhut' Lizo Ndixolele by Mbekeni and Ntloko, expresses hostility and hatred towards her daughter-in-law, Nobantu. The reason for this is that her son died before they could have children. Because of this, MamXebise blames Nobantu for being barren.

MamXebise: Kakade andiyiboni into osayihlaleleyo apha xa ufelwe yindoda. Ungahlala nendoda iinyanga ezingaka kanti iza kufa ingashiyanga nto eya kuba ngumfanekiso wayo. Ndiza kulenza ntoni mna idlolokazi? (Mbekeni \& Ntloko, 1979:56-57.)

For that matter I do not see the reason why you are staying here when your husband is dead. How can you stay with a man for so many months and he died without having a child who will 
remain his picture? What am I going to do with a barren woman?

MamXebise, being a woman, is inflicting more pain on Nobantu who has already been hurt by the death of her husband. Socialisation for inequality can be one of the banes of women's lives. It can also prevent them from sympathising with other women. It can encourage them to feel satisfaction when they make other women unhappy, as other women did to them in childhood.

In traditional African culture it is the old women who ensure that patriarchal traditions are enforced and reproduced. Okoboshi's mother and her female relations in The bride price (Emecheta, 1995), give a white towel to Okoboshi in order for him to sleep with Akunna. They assure Akunna with a smile that it won't be painful.

The others laughed at the grimace on her face, and again assured her that it would not be painful and that Okoboshi had been particularly instructed to be gentle with her. (Emecheta, 1995:140.)

These women oppress Akunna simply because they were sexually oppressed in the same way. They want to make it worse for the other person. In The bride price, on the night of the day when Akunna celebrates her womanhood (menstruation), she is attacked by a man called Okoboshi who squeezes her breasts very painfully.

Without warning, Okoboshi walked up to Akunna and seized her roughly at the back of her shoulder. He grabbed both breasts and started to squeeze and hurt her. (Emecheta, 1995:124.)

Akunna suffers patriarchy's psychic and societal repression of women. The phallic order is disconnecting her sexual being from her maternal being so that she (Akunna) can serve the basic reproductive and economic needs of the culture, as her body is viewed as an object of sexual pleasure for men. Akunna's mother, instead of fighting against what Okoboshi has done, condones it. Menstrual blood that is supposed to build a strong relationship between Akunna and her mother, Ma Blackie, instead separates them through patriarchal and cultural customs. It destroys the bond between mother and daughter instead of intensifying it. Ma Blackie utters these words:

You mean you have nice breasts and don't want men to touch them? Girls like you tend to end up having babies in their father's house because they cannot endure open play, so they 
go to secret places and have themselves deflowered. (Emecheta, 1995:131.)

Frank (1987:16) contends that like their daughters' suitors and husband, these mothers want to see their daughters securely married and perpetually pregnant. They cannot imagine a destiny for their daughters other than the one they have endured.

Ma Blackie found herself deeply immersed in the Okonkwo (her husband's) family politics. As indicated by Brown-Guillory (1996), the very least Ma Blackie can do is to make Akunna fit enough to obtain a healthy bride price. Brown-Guillory continues that women who have many daughters console and congratulate themselves in terms of the expensive bride prices these daughters might bring.

\subsection{Arranged marriage}

Marriage is regarded as important in African culture. Mbiti (1969: 133) underlines this idea.

For African people, marriage is the focus of existence. It is the point where all the members of a given community meet: the departed, the living and those yet to be born ... Marriage is a drama in which everyone becomes an actor or actress and not just a spectator. Therefore, marriage is a duty, a requirement from the corporate society, and a rhythm of life in which everyone must participate.

Mbiti states that marriage is not an option but a necessity in which everyone in that society is expected to participate. In isiXhosa, an arranged marriage is known as ukutshatisa ngebhaxa. This type of marriage is a marriage that comes into being against the will of one of the people involved. In some cases it can happen without the consent of either spouse, like when a family of a girl or a man arranged the marriage of their children without involving them in the process. In most cases this happens to benefit the family of the girl with the lobola. Odetola (1983:20) says the marriage was therefore arranged through the orders of the parents and the words of the gobetween. This means that traditionally it is the duty of the parents to arrange marriage for their children. Nkumane (1999:145) says the tradition of forcing a child to marry a man or woman that he/she does not love, clearly reflects the way in which men, in particular, abuse their powerful positions in society, either as rulers of their nations, or as heads of their families. She says further that it shows how men transfer the abuse of power in the public sphere to their family unit. Sando Cikizwa's father in UDike no Cikizwa by Mmango, 
displays his authority as the head of the house by disputing everything his wife and his sisters say about Cikizwa. Cikizwa's mother is telling Sando that Cilkizwa is sick because her family has arranged that she marry a man she has never loved. Sando's response is:

Sando: (efudumala ngumsindo): Nina! Niza kundiphambanisa. Ukugula kwalo mntwana akusayi kundijika kwisigqibo sam. Uza kutshata noMjongwa ethanda engathandi. Ngaba akasayi kuze aphile. Uya kugula ad'agobe! (Mmango, 1991:11.)

(Becoming angry): You! You are going to make me mad. The fact that this child is sick is not going to change my decision. She is going to get married to Mjongwa, like it or not. She will get sick until she gets old.

Sando is exerting his power as father and as head of the family. He forces Cikizwa to get married to a man she does not know, because he is looking to gain livestock from the family of the man. He does not care for the health of his child. The only thing that he does not want to lose is the lobola that he is going to get from Mjongwa's family. The feelings of Cikizwa, and that of other women in the family, are ignored. The proof that Sando is more after gain than helping his child to get a good husband, is the words he speaks to Dike, who is in love with Cikizwa, but they are being separated by the arranged marriage. Sando meets Dike, but before he kills him, as he perceives him to be the one who influenced Cikizwa not to be co-operative in the marriage that he is arranging for her, he says:

Sando: Ukunyaniseka kothando Iwakho kuCikizwa kuza kundiphulukanisa neshumi elinesihlanu leenkomo, amashumi amabini eegusha neli hashe ndiliqabeleyo, njandini! (Mmango, 1991:48.)

Your loyalty to your love for Cikizwa is going to make me lose fifteen cows, twenty sheep, together with this horse I am riding, dog!

Sando's words prove that he is after wealth, not the happiness of his child. Potash (quoted in Stichter \& Hay, 1995:83) says that in some places and among some families, an arranged marriage is used to benefit the father of the daughter concerned. Sando uses derogative language to chase away his sister who is concerned about Cikizwa's health, because he does not want to listen to anyone who is trying to stop him from marrying Cikizwa off to Mjongwa, the man she does not love. 
Sando: $\quad$ Musa ukundifundekela. Nokuba ufile lo mntwana ngowam. (Mmango, 1991:11.)

Don't make a noise. Even if this child dies, she is mine.

In the above statement, Sando uses derogatory words to make his sister afraid of him and to stop her asking questions about his intentions of marrying Cikizwa. His arrogance shows that he is the powerful figure in his family and the one who controls the situation. He does not want advice from women. He regards what he is doing as a good gesture of finding a good and wealthy home for his daughter. Cikizwa's words, on the other hand, prove that she does not love Mjongwa and that her father is forcing her to marry him. She loves Dike, the love of her life. Cikizwa is in conversation with Nomazala, her father's sister, who is trying to convince Cikizwa to accept what Sando is trying to organise for her. Cikizwa says:

Cikizwa: Ndibuthathaka, ndithambile, ndifuna ukuphathwa ngezandla ezithambileyo zothando. Umntu onezo zandla ngu Dike kuphela. (Mmango, 1991:10.)

I am weak and fragile; I want to be held by soft hands of love. The only person with those hands is Dike.

Cikizwa sees Dike as the only person who would be able to look after her with love, tenderness and care. Cikizwa's human rights cannot be expressed fully because she is a female and moreover a minor to her father who cannot give voice to her feelings.

In Buzani kubawo by Tamsanqa Thobeka suffers under the power of the traditional culture of arranged marriages because she had to accept marriage to Gugulethu according to her parents' wishes.

Thobeka: Kowu! Bandenza abazali bam ngokuhlala bahlale bandizise kwisilingo esinje ngesi ndikuso ndibaxelela. (Tamsanqa, 1987:83.)

Wow! My parents have done me wrong by putting me in this position, despite what I told them.

Thobeka's wishes are ignored by her parents. They follow the traditional way of doing things and do not consider their child's wishes and feelings. In traditional society, it is often the case that women become victims of forced and forbidden love. Thobeka, together with her children, ended up being brutally murdered by Gugulethu, a man she was forced by her parents to marry. 
In The joys of motherhood Emecheta portrays the misery and frustration that arranged marriage can cause. Agabadi, NnuEgo's father, chooses a serious husband for his daughter. He even ignores Idayi's advice that he needs to change with the times. He becomes adamant in his views because his clan supports him, as they believe that a woman cannot hate a man chosen for her by her people. NnuEgo's first sight of her husband, Nnaife, embarrasses her. She even hates the way he is physically built, most especially his protruding belly.

... and was just falling asleep with a full stomach like a man with a belly like a pregnant cow, wobbling first to this side and then to that. The belly, coupled with the fact that he was short, made him look like a barrel ... If her husband-to-be was like this, she thought, she felt like bursting into tears, like begging the senior Owulum to please take her home. (Emecheta, 1988:42-43.)

NnuEgo cannot believe that her father sent her to marry this kind of person who is not even good looking. But because of her respect for her father and for her tradition she learns to live with him, although she shows signs of unhappiness and dissatisfaction. This also nearly spoils their marriage because she always clashes with her husband, as she does not have any affection for him.

\section{Conclusion}

From the above discussion it is clear that women are the people who are mostly affected by gender inequality. Traditional culture often plays a prominent role in oppressing women. Men often have used and still use traditional culture in order to benefit themselves at the expense of women. The way men hold on to these gender inequalities shows that somewhere in their subconscious mind, they fear that, if they give women a chance, they will be overpowered. Looking at the above examples we can see that equality still remains a distant ideal, because traditional African culture in many ways still discourages equality between the sexes. Many African people still do not want to accept the changes. There are only a few who accept the fact that there is a need to value women's efforts without comparing them to anyone else's. Women are not ashamed of being called women, but they do not want to be looked down upon because of their sex. They want to be described as whole persons and be judged according to their contribution to society. 


\section{List of references}

BRESSLER, C.E. 1994. Literary criticism: an introduction to theory and practice. Upper Saddle River: Prentice Hall.

BROWN-GUILLORY, E. 1996. Women of color: mother-daughter relationship in 20th century literature. Austin: University of Texas Press.

CLAYTON, C. 1989. Women and writing in South Africa. Marshall Town: Heinemann.

DYAFTA, N. 1953. Ikamva lethu. Alice: Lovedale.

ECKERT, P. \& McCONNELL-GINET, S. 2003. Language and gender. Cambridge: Cambridge University Press.

EMECHETA, B. 1988. The joys of motherhood. London: Heinemann.

EMECHETA, B. 1995a. The bride price. London: Heinemann.

EMECHETA, B. 1995b. The slave girl. London: Heinemann.

FRANK, K. 1987. Women without men: the feminist novel. London: Women's Press.

GALOMBOK, S. \& FIVUS, R. 1994. Gender development. London: Cambridge University Press.

JACKSON, S. \& SCOTT, S. 2002. Gender: a sociological reader. New York: Routledge.

JAMES, A. 1990. In their own voices: African women writers talk. London: Heinemann.

JARRET-MACAULEY, D. 1996. Reconstructing womanhood, reconstruction feminism: writings on black women. London: Routledge.

JONES, E.A. \& OLSON, G.A. 1991. The gender reader. London: Allyn \& Bacon.

KESSLER, S.J. \& MCKENNA, W. 1978. Gender. New York: John Wiley.

KRAMARAE, C. \& TREICHLER, P.A. 1995. A feminist dictionary. Ontario: Pandora Press.

KRIGE, E.J. 1974. The social system of the Zulus. Pietermaritzburg: Shuter \& Shooter.

LEE, G.R. 1982. Family structure and interaction: a comparative analysis. Minneapollis: University of Minnesota Press.

MAGADLA, V. 1992. Isazela sidl' umniniso. Pietermaritzburg: Centaur.

MBEKENI, N. \& NTLOKO, P.M. 1979. Bhut'Lizo Ndixolele. Alice: Lovedale.

MBITI, J.J. 1969. African religions and philosophy. London: Heinemann.

MMANGO, A. 1991. UDike noCikizwa. Alice: Lovedale.

MOTHLABANE, H. 1994. linkunzi Ezimbini. Isando: Heinemann.

MTINGANE, A. 1992. Inene nasi Isibhozo. Cape Town: Via Afrika.

NKUMANE, K. 1999. Theme of forced and forbidden love: cross cultural trends in language literature with special reference to the Zulu novel. Pietermaritzburg: Vista University. (Unpublished Ph.D. thesis.)

NWAPA, F. 1979. Efuru. London: Heinemann.

ODETOLA, T.O. 1983. Man and society in Africa: an introduction to sociology. London: Longman.

OGUNDIPE-LESLIE, M. 1994. Re-creating ourselves: African women \& critical transformations. Trenton: Africa World Press.

PILCHER, J. \& WHEELEHAN, I. 2004. 50 Key concepts in gender studies. London: Sage.

REBER, A. 1985. Dictionary of psychology. Harmondsworth: Penguin.

$\mathrm{RICH}$, A. 1977. Born: motherhood as experience and institution. London: Heinemann. 
ROHRBAUGH, J. 1981. Women: psychology puzzle. London: Abacus.

RUTH, S. 1980. Issues in feminism: a first course in women's studies. Boston: Houghton Mifflin.

RUTHVEN, H. 1984. Stereotype and reality. New York: Routledge.

STICHTER, S. \& HAY, M.J. 1995. African woman: South of the Sahara. London: Longman.

SWARTBOOI, V. 1975. UMandisa. Alice: Lovedale.

TAMSANQA. 1987. Buzani kubawo. Cape Town: Oxford University Press.

TINKER, I. 1990. Persistent inequalities: women and world development. New York: Oxford University Press.

WALBY, S. 1990. Theorizing patriarchy. Oxford: Blackwell.

WEEDEN, C. 1987. Feminist practice and poststructuralist theory. Oxford: Blackwell.

WILENTZ, G. 1992. Binding cultures: black women writers in Africa and the diaspora. Indiana: Indiana University Press.

ZINSSER, J.P. 1993. History and feminism: a glass half full. New York: Twayne Publishers.

\section{Key concepts:}

gender

patriarchy

polygamy

stereotype

\section{Kernbegrippe:}

gender

patriargie

poligamie

stereotipe 